\title{
Assessment of Antimicrobial Efficacy of Nano Chitosan, Chlorhexidine, Chlorhexidine/Nano Chitosan Combination versus Sodium Hypochlorite Irrigation in Patients with Necrotic Mandibular Premolars: A Randomized Clinical Trial
}

\author{
Maha Nasr ${ }^{1 *}$ (D) Alaa Diab ${ }^{2}$, Nehal Nabil Roshdy ${ }^{2}$, Amira Hussein $^{3}$ iD \\ ${ }^{1}$ Department of Endodontics, Faculty of Dentistry, Egyptian Russian University, Badr City, Cairo Governorate, Egypt; ${ }^{2}$ Department \\ of Endodontics, Faculty of Dentistry, Cairo University, Giza, Egypt; ${ }^{3}$ Department of Clinical and Chemical Pathology, Faculty of \\ Medicine, Cairo University, Giza, Egypt
}

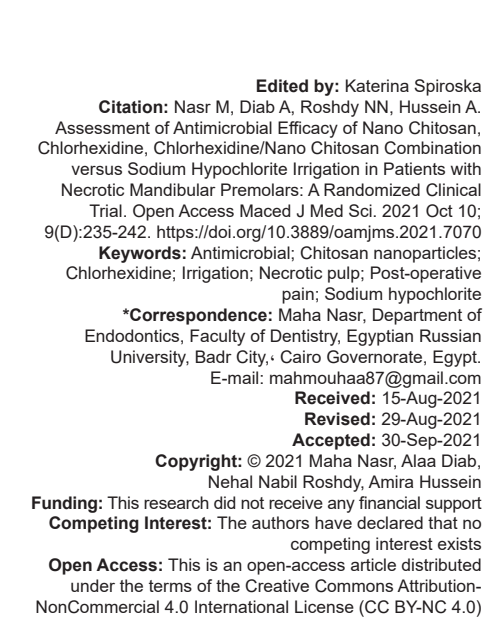

\begin{abstract}
AIM: The study was done to assess the antimicrobial effectiveness of Chitosan Nanoparticles (CNPs), Chlorhexidine $(\mathrm{CHX})$, and their combination ( $\mathrm{CHX} / \mathrm{CNPs})$ versus that of Sodium hypochlorite $(\mathrm{NaOCl})$ in patients with mandibular necrotic premolars and to evaluate their effects on post-operative pain after single-visit endodontic treatment.

MATERIALS AND METHODS: Sixty patients with necrotic mandibular premolars were divided randomly to four groups $(n=15)$ according to the used irrigating solution. Instrumentation was done using rotary ProTaper files. During instrumentation, irrigation was done using $2.5 \% \mathrm{NaOCl}$; afterward, canals were flushed with sterile saline. A final flush with the study irrigants was done as follows: $3 \%$ CNPs for Group A, 2\% CHX for Group B, CHX/CNPs for Group C, and $5.25 \% \mathrm{NaOCl}$ for Group D. Samples were collected from root canals before and after canal preparation then cultured to assess the number of colony-forming units $/ \mathrm{ml}$. All patients were instructed to record their pre- and post-operative pain levels on a numerical rating scale.

RESULTS: CNPs and CHX/CNPs were significantly more effective than either $\mathrm{CHX}$ or $\mathrm{NaOCl}$; however, there was no significant difference between them against anaerobic bacteria. All tested irrigants were similarly effective against aerobic bacteria. CNPs and CHX/CNPs were associated with significantly lower post-operative pain levels in the first $24 \mathrm{~h}$ after treatment.

CONCLUSIONS: CNPs and its combination with $\mathrm{CHX}$ are significantly more effective than both $\mathrm{CHX}$ and $\mathrm{NaOCl}$ against anaerobic bacteria isolated from necrotic mandibular premolars. Post-operative pain intensity was significantly lower with CNPs and CNPs/CHX combination than with either $\mathrm{NaOCl}$ or $\mathrm{CHX}$.
\end{abstract}

\section{Introduction}

Bacteria play an essential role in pathogenesis of apical periodontitis; therefore, success of root canal treatment depends on its eradication before root canal obturation [1]. Bacteria remaining within the root canal system after obturation can contribute to endodontic failures [2]. Different studies that used modern techniques such as micro computed tomography scanning to assess the effects of instrumentation on root canals after using different techniques have concluded that proportionally great parts of the root canal walls remained unprepared by the endodontic instruments enhancing the value of chemical preparation [3]. Therefore, the major challenge during endodontic retreatment is to efficiently disinfect the entire pulp space before filling.

Sodium hypochlorite $(\mathrm{NaOCl})$ has been used for decades in the treatment of both primary and secondary endodontic infections [4], [5]. However,
$\mathrm{NaOCl}$ possesses many drawbacks including irritation of the periapical tissues and burning of surrounding oral tissues [6], [7]. On the other hand, chlorhexidine ( $\mathrm{CHX})$, the available alternative to $\mathrm{NaOCl}$, despite being nontoxic and non-irritant and significantly effective against bacteria [7], [8], [9], [10], lacks any tissue dissolving abilities.

Despite the recent advancements in root canal treatment strategies, the failure rate did not decrease below $18-26 \%$ in the past 50 years; this could be attributed to the inability of current techniques to deal with the disease process as a whole and the lack of capable strategies to destroy bacterial biofilm during treating infected root canals. Therefore, more advanced disinfection techniques and irrigants are being investigated [11].

Many studies were conducted to assess new irrigants aimed to obtain irrigating solutions that are more effective and less irritating to the periapical tissues than $\mathrm{NaOCl}$ shedding the light on a wide range 
of natural substances such as Chitosan [7], Propolis, herbal solutions [11], [12], [13], and antibacterial nanoparticles [14], [15] that are alleged to be as efficient against bacteria as $\mathrm{NaOCl}$, while being less toxic and less irritant.

Chitosan is a naturally occurring polysaccharide derived from the shells of crustaceans. It is nontoxic, biocompatible, and biodegradable. Its use in the field of endodontics was based on its broad-spectrum antimicrobial activity and considerable chelating effects [16]. Nanoparticles possess better antimicrobial activity thanks to their polycationic/polyanionic nature together with their high surface area and charge density, providing more interaction with the bacterial cells [17]. Therefore, chitosan nanoparticles (CNPs) have been employed in different health-care domains including root canal therapy [18].

None of the studies in the literature has evaluated the antibacterial effects of CNPs as an irrigating solution against primary endodontic infections. The null hypothesis is that there is no difference in the antimicrobial efficacy or post-operative pain amongst CNPs, $\mathrm{CHX}, \mathrm{CHX} / \mathrm{CNPs}$ combination, and $\mathrm{NaOCl}$ in root canal treatment. Hence, the purpose of our study was to assess the antibacterial effects of CNPs alone or loaded with $\mathrm{CHX}$ compared to those of $\mathrm{NaOCl}$, as well as their effects on post-operative pain after single-visit root canal treatment in patients with necrotic mandibular premolars.

\section{Materials and Methods}

\section{Study design}

This was a prospective, four- arm, parallel- group, double-blinded, randomized, and clinical trial.

\section{Setting and Recruitment}

The trial protocol was registered on www. clinicaltrials.gov (ClinicalTrials.gov Identifier: NCT03668899) and was approved by the Committee of Research Ethics, Faculty of Dentistry, Cairo University. The study nature, objectives, benefits, and risks were thoroughly described to all recruits then the ones accepting enrolment signed a written consent form. Participants were recruited from the outpatient clinic, Department of Endodontics, Faculty of Dentistry, Cairo University between June 2019 and January 2020.

\section{Sample size calculation}

Based on an earlier study by Shingare and Chaugule [6], the difference in bacterial count amongst at least two groups is $75 \pm 75$. Using $80 \%$ power and
$5 \%$ significance level, it was 12 subjects were required per group. The number was raised to a sample size of 15 subjects per group to compensate for follow-up losses. Sample size calculation was performed with the PS: Power and Sample Size Calculation Software, Version number 3.1.2 (Vanderbilt University, Nashville, Tennessee, USA).

\section{Randomization, allocation concealment, and blinding}

A random sequence was created on (https:// www.random.org/), assigning the patients at random to one of four groups with a 1:1 allocation ratio as follows: Group A: CNPs. Group B: CHX, Group C: CHX/ CNPs combination, and Group D: $5.25 \% \mathrm{NaOCl}$. The generated numbers were written in small eight-times folded opaque papers then insert into opaque sealed envelopes and signed across the seal. The envelops were placed in a container for each participant to grasp one envelope before the final flush with any of the tested irrigating solutions/suspensions. Both the participants and the microbiologist were blinded to the interventions. The steps of the treatment as stated in the informed consent form were explained to the participants without knowing which irrigants is to be used for the root canal final flush. Blinding to the microbiologist was done by hindering sequence generation, allocation concealment, and treatment options.

\section{Preparation and characterization of the nanoparticles}

\section{Preparation}

CNPs were prepared to a suspension form by the ionotropic gelation technique [19] using poly anion sodium tripolyphosphate TPP as a crosslinking agent. $\mathrm{CHX}$ loaded CNPs: To get $\mathrm{CHX} 2 \%$ in final concentration an appropriate amount was used $(75 \mathrm{ml}$ ) and evaporated to $7.5 \mathrm{ml}$ then added to CNPs suspension with stirring and sonication for $1 \mathrm{~h}$.

\section{Characterization}

The size and shape of the prepared nanoparticles were confirmed by transmission electron microscopy (TEM). The resultant suspension showed white spherical particles with an average size $<50 \mathrm{~nm}$.

\section{Eligibility criteria}

Eligible participants were medically free adults of both sexes with age range between 22 and 45 years suffering from asymptomatic necrotic mandibular premolars. Exclusion criteria included patients with vital inflamed pulps, symptomatic periapical abscess or previous endodontic treatment. 


\section{Endodontic procedures}

Medical and dental histories were obtained and recorded in medical and dental history charts. Pain scale chart was provided to each patient to record his/ her pain level before any endodontic treatment as a reading for the preoperative pain level. Patients were then asked to fill a pain dairy at $6,12,24,48,72 \mathrm{~h}$, and 7 days postoperatively accurately and honestly then return it to the operator on time. An numerical rating scale (NRS), which was translated into Arabic, was used to record pain levels. The NRS is an 11 point scale anchored by two extremes "No pain" and "pain as bad as it could be." Pain level was assigned to one of four categorical scores: None (0); Mild (1-3); Moderate (4-6); and Severe (7-10). Participants were asked to choose the mark that represented their pain level.

Patients were anaesthetized then rubber dam isolation was done to maintain aseptic field. The offending tooth and its surroundings were disinfected with $3 \%$ hydrogen peroxide and $2.5 \% \mathrm{NaOCl}$ before and after coronal access cavity preparation. Working length was determined at first by an apex locator then confirmed by a periapical radiograph to be adjusted at $1 \mathrm{~mm}$ shorter of the radiographic apex.

All canals were then mechanically instrumented in a crown-down approach using rotary ProTaper Universal files reaching up to size \#F4. During preparation canals were thoroughly irrigated for $1 \mathrm{~min}$ between every two successive files using $2 \mathrm{ml}$ of $2.5 \% \mathrm{NaOCl}$. After complete preparation, all canals were flushed with EDTA followed by sterile saline to be ready for the final flush with either of the tested irrigants according to the randomly assigned group. At this point, the canals were flushed for 5 min using $5 \mathrm{ml}$ of either of the study irrigants; $3 \%$ Nano Chitosan, $2 \% \mathrm{CHX}$, combination of $\mathrm{CHX}$ and Nano Chitosan, or $5.25 \% \mathrm{NaOCl}$ using a 29-gauge side-vented needle in a plastic syringe inserted $1 \mathrm{ml}$ shorter of the working length. Irrigation activation was done by manual dynamic agitation using a well-fitting master cone (\#40, taper $4 \%$ ) pumped up and down in rapid, short (2-3 ml) vertical strokes.

All canals were completely dried using paper points size 40 and obturated with modified single cone technique utilizing a \# 30 spreader to create space for \#25 auxiliary cones in the coronal third alongside the well-fitted special F4 ProTaper master cone.

All participants had post-treatment instructions, were asked to call the operator in case of moderate to severe pain; and were allowed to take Ibuprofen $400 \mathrm{mg}$ (Brufen 400, Kahira Pharm. and Chem. Ind. Co., under licence from Abbott Laboratories) as prescribed. The patients were also informed to contact the dentist to schedule an emergency intervention should the pain persist.

\section{Microbiological procedures}

Initial sampling

Two initial samples S1 were collected from each root canal before preparation using sterile \#15 paper points. Sterile saline was injected in the canals followed by the insertion of a \#15 K-file to the predetermined working length to facilitate the insertion of the paper points to collect the samples. Every paper point remained in place at least for $1 \mathrm{~min}$ then immediately placed in test tubes containing either freshly prepared Cary Blair as a transport medium specific for preservation of common anaerobic bacteria or phosphate buffered saline PBS as a transport medium for aerobic bacteria then sent to the Microbiology Laboratory, Faculty of Medicine, Cairo University for processing.

\section{Final sampling}

After flushing the canals with each irrigating solution, all canals were rinsed with $10 \mathrm{ml}$ sterile saline before collecting the final sample S2 using a sterile \# 40 paper point in the same manner as S1.

The collected samples were cultured in serial dilution on blood agar plates under anaerobic and aerobic conditions, incubated for $48 \mathrm{~h}$, followed by counting the number of colony-forming units per $\mathrm{ml}$ (CFUs/ml).

\section{Statistical methods}

Data were analyzed using IBM SPSS advanced statistics (Statistical Package for the Social Sciences), version 21 (SPSS Inc., Chicago, IL). Numerical data were described as mean and standard deviation or median and range. Data were explored for normality using Kolmogorov-Smirnov test and Shapiro-Wilk test. Comparisons among four groups for normally distributed numeric variables were done using the ANOVA; however, non-normally distributed numeric variables were done by Kruskal-Wallis test. $p \leq 0.05$ was considered statistically significant. All tests were two tailed. Categorical data were described as numbers and percentages and comparisons were done using Chi-square test or fisher exact as appropriate.

\section{Results}

Of 67 patients screened for eligibility, 60 were included, and randomly enrolled. All patients' data were analyzed with no dropout. The gender distribution was 27 females and 33 males. Participants' age ranged between 22 and 45 years. The study included 26 first 
Table 1: Baseline characteristics of the included study participants

\begin{tabular}{|c|c|c|c|c|c|}
\hline & Group A & Group B & Group C & Group D & $\mathrm{p}$-value \\
\hline \multicolumn{6}{|l|}{ Age } \\
\hline Median (range) & $29(23-45)$ & $31(24-42)$ & $29(23-41)$ & $29(22-41)$ & 0.464 \\
\hline \multicolumn{6}{|l|}{ Gender } \\
\hline Male $\mathrm{n}(\%)$ & $7(46.7 \%)$ & $6(40 \%)$ & $7(46.7)$ & $7(46.7 \%)$ & 0.977 \\
\hline Female $\mathrm{n}(\%)$ & $8(53.3 \%)$ & $9(60 \%)$ & $8(53.3 \%)$ & $8(53.3 \%)$ & \\
\hline \multicolumn{6}{|l|}{ Tooth type } \\
\hline $1^{\text {st }}$ premolar $\mathrm{n}(\%)$ & $6(40 \%)$ & $6(40 \%)$ & $7(46.7 \%)$ & $7(46.7 \%)$ & 0.965 \\
\hline $2^{\text {nd }}$ premolar $n(\%)$ & $9(60 \%)$ & $9(60 \%)$ & $8(53.3 \%)$ & $8(53.3 \%)$ & \\
\hline Preoperative anaerobic CFUs Median (range) & $8.03 \times 10^{7}\left(71 \times 10^{3}-141 \times 10^{3}\right)$ & $7.99 \times 10^{7}\left(6.97 \times 10^{7}-9.14 \times 10^{7}\right)$ & $7.4 \times 10^{7}\left(5.12 \times 10^{7}-9.6 \times 10^{7}\right)$ & $7.3 \times 10^{7}\left(6.27 \times 10^{7}-9.24 \times 10^{7}\right)$ & 0.831 \\
\hline Preoperative aerobic CFUs Median (range) & $92 \times 10^{3}\left(6.89 \times 10^{7}-9.41 \times 10^{7}\right)$ & $98 \times 10^{3}\left(78 \times 10^{3}-128 \times 10^{3}\right)$ & $89 \times 10^{3}\left(66 \times 10^{3}-219 \times 10^{3}\right)$ & $101 \times 10^{3}\left(79 \times 10^{3}-144 \times 10^{3}\right)$ & 0.343 \\
\hline
\end{tabular}

and 34 second mandibular premolars. Baseline data were similar for all groups $(p \geq 0.05)$ (Table 1).

The CNPs group showed the least anaerobic bacterial colony count followed by the CHX/CNPs group but they were not significantly different from one another $(p \geq 0.05)$. Both groups had significantly lower CFUs count than $\mathrm{NaOCl}$ and $\mathrm{CHX}$ groups $(p<0.05)$. $\mathrm{NaOCl}$ group showed a significantly lower CFUs count than $\mathrm{CHX}$ group $(p<0.05)$. All the tested irrigants had similar effectiveness against aerobic bacteria with no significant differences among them $(p \geq 0.05)$ (Table 2).

A statistically significant difference was found in the post-operative pain scores among groups only after 12 and 24 h postoperatively $(p<0.05)$. Post-operative pain scores gradually decreased with time over 7 days postoperatively (Table 3 ).

\section{Discussion}

Mechanical root canal preparation involves the removal of all tissues (vital or necrotic) aim to eliminate pulp space infection. In addition, the anatomical complexity of the root canal system leaves hidden areas inaccessible to the endodontic instruments. Therefore, mechanical preparation cannot be performed without use of chemical disinfection and the process was referred to as biomechanical or chemo mechanical preparation [20].

$\mathrm{NaOCl}$ is still considered the gold standard irrigating solution and is widely popular in Endodontics. Thus, it was used in the current study as a comparator. In the current study $5.25 \% \mathrm{NaOCl}$ was used as it was proved to be the only concentration able to leave root canals free of Enterococcus faecalis, one of the most resistant microorganisms in endodontic infections, in contrast to $1.3 \%$ and $2.5 \%$ concentrations [21].

About $2 \% \mathrm{CHX}$ was used in the study owing to its broad-spectrum antimicrobial activity and substantivity as a root canal irrigating solution. It also overcomes the drawbacks of $\mathrm{NaOCl}$ [7], [6].
CNPs of a size $50 \pm 5 \mathrm{~nm}$ at a concentration of $3 \%$ were used. It has been suggested that $3 \%$ CNPs solution has a positive bactericidal effect as a root canal irrigants against $E$. faecalis and the same effect occurred when compared with $2.5 \% \mathrm{NaOCl}$ [22]. It was also demonstrated that CNPs with average size of $97 \mathrm{~nm}$ showed a strong bactericidal action against both Gram-negative and Gram-positive bacteria [23].

The combination of $2 \% \mathrm{CHX}$ and $3 \%$ CNPS was used to explore the ability of CNPs to act as a vehicle to deliver $\mathrm{CHX}$ into dentinal tubules as it has been shown in the previous studies that the antimicrobial abilities of CNPs have been enhanced by loading them with other antimicrobial agents [24].

Mandibular premolars were selected in our study since their canals are oval buccolingually representing a challenge for clinicians to properly instrument. Mechanical preparation of oval canals creates buccal and lingual untouched recesses, which can retain necrotic tissues remnants, bacterial biofilms and packed dentin debris. These infected debris can provide a viable source of persistent infection and endodontic treatment failure [25].

After chemo mechanical preparation, the canals were rinsed with $2.5 \% \mathrm{NaOCl}, 17 \%$ EDTA to eliminate the smear layer and open the dentinal tubules [26]. A final flush with sterile saline solution was mandatory to eliminate residual chemical activity of the used agents during preparation to be ready for the final flush with the experimental solutions [27].

Initial samples (S1) and final samples (S2) were collected using sterile paper points. Sampling of the root canal contents using paper points was proven to be better in detecting bacteria than dentin filing samples [28]. Bacterial culture method was used to assess the antibacterial effectiveness in the current study since it is widely available, and allows for accurate quantification of viable cultivable microorganisms in samples [29].

A NRS was used for measuring the intensity of pain. The NRS is a simple scale that provides higher sensitivity than the verbal rating scale and less complexity than the visual analog scale [30]. Evaluation

Table 2: The median and range values of post-operative anaerobic and aerobic bacterial count in the four Groups

\begin{tabular}{|c|c|c|c|c|c|}
\hline & Group A & Group B & Group C & Group D & $\mathrm{p}$-value \\
\hline Post-operative anaerobic CFUs Median (range) & $77 \times 10^{3}\left(52 \times 10^{3}-108 \times 10^{3}\right)$ & $124 \times 10^{3}\left(83 \times 10^{3}-161 \times 10^{3}\right)$ & $88 \times 10^{3}\left(41 \times 10^{3}-104 \times 10^{3}\right)$ & $89 \times 10^{3}\left(51 \times 10^{3}-149 \times 10^{3}\right)$ & $<0.001^{*}$ \\
\hline Post-operative aerobic CFUs Median (range) & $19 \times 10^{2}\left(7 \times 10^{2}-28 \times 10^{2}\right)$ & $17 \times 10^{2}\left(9 \times 10^{2}-31 \times 10^{2}\right)$ & $17 \times 10^{2}\left(7 \times 10^{2}-49 \times 10^{2}\right)$ & $19 \times 10^{2}\left(15 \times 10^{2}-29 \times 10^{2}\right)$ & 0.541 \\
\hline
\end{tabular}


of the pain intensity was done preoperatively, and after $6,24,48,72 \mathrm{~h}$, and 7 days. The previous studies agreed that endodontically treated teeth weather vital or non-vital showed high post-operative pain scores within the first $24 \mathrm{~h}$ [31], [32], [33]. The above-mentioned time points were chosen as most previous studies used them to assess post-operative pain [34], [35].

Table 3: Median, minimum, maximum values, and $p$ value for comparison of NRS scores among the four groups

\begin{tabular}{|c|c|c|c|c|c|}
\hline & Group A & Group B & Group C & Group D & $p$-value \\
\hline Preoperatively & & & & & \\
\hline $\begin{array}{l}\text { Median (range) } \\
\text { After } 6 \mathrm{~h}\end{array}$ & $1(0-3)$ & $0(0-3)$ & $1(0-2)$ & $1(0-2)$ & 0.945 \\
\hline $\begin{array}{l}\text { Median (range) } \\
\text { After } 12 \mathrm{~h}\end{array}$ & $6(4-8)$ & $6(4-8)$ & $5(3-8)$ & $6(3-8)$ & 0.673 \\
\hline $\begin{array}{l}\text { Median (range) } \\
\text { After } 24 \mathrm{~h}\end{array}$ & $4(2-7)$ & $4(4-8)$ & $3(1-7)$ & $4(3-8)$ & $0.014^{*}$ \\
\hline $\begin{array}{l}\text { Median (range) } \\
\text { After } 48 \mathrm{~h}\end{array}$ & $3(2-4)$ & $3(2-5)$ & $1(1-4)$ & $2(1-5)$ & $0.002^{*}$ \\
\hline $\begin{array}{l}\text { Median (range) } \\
\text { After } 72 \mathrm{~h}\end{array}$ & $1(0-2)$ & $1(0-2)$ & $0(0-2)$ & $0(0-2)$ & 0.475 \\
\hline $\begin{array}{l}\text { Median (range) } \\
\text { After } 7 \text { days }\end{array}$ & $0(0-2)$ & $0(0-2)$ & $0(0-2)$ & $0(0-1)$ & 0.53 \\
\hline Median (range) & $0(0-2)$ & $0(0-4)$ & $0(0-2)$ & $0(0-1)$ & 0.818 \\
\hline
\end{tabular}

A significant difference was detected in the anaerobic bacterial colony counts (CFU/ml) after irrigation among the four groups. Group A (3\% CNPs) exhibited the best results being significantly better than both Group B (2\% CHX) and Group D (5.25\% $\mathrm{NaOCl})$. However, there was no significant difference between Groups A (3\% CNPs) and Group C (CNPs/ $\mathrm{CHX}$ combination).

These results agreed with the findings of Perochena et al. [36] who showed that CNPs solution was significantly better than $\mathrm{NaOCl}$ and contradicted those of Roshdy et al. [22] and Moukarab [37] who found no significant difference between CNPs and $\mathrm{NaOCl}$. The difference in findings could be attributed to the different circumstances, where they tested the solutions in vitro against $E$. faecalis biofilm while the current study tested them clinically against the multispecies primary endodontic infection.

The non-significant difference between CNPs and $\mathrm{CHX/CNPs}$ combination in the current study disagreed with the findings of Barreras et al. [38] who suggested a synergistic effect between both solutions. This might be attributed to the different study conditions as they used smaller CNPs concentrations $(0.015 \%)$ and tested it against $E$. faecalis using $\mathrm{BHI}$ agar diffusion test.

The mode of action of chitosan as an antibacterial agent has been explained by many theories. One theory is based on contact mediated killing where the positively charged chitosan interferes with the phosphoryl group of bacterial cell membrane, resulting in increased membrane permeability, leakage of proteins, cellular components, and eventually bacterial cell death. Being a chelating agent, chitosan has also been suggested to inhibit the bacterial growth by metal chelation that reduces enzyme activity [39]. On the nano scale, CNPs can penetrate bacterial cell, bind to its deoxyribonucleic acid (DNA) and block RNA transport. It can also prevent the process enzymatic degradation by which bacteria penetrates into dentinal tubules [39].

The results showed that $5.25 \% \mathrm{NaOCl}$ had a significantly higher effect against bacteria than $2 \% \mathrm{CHX}$. This agreed with the findings of Agrawal et al. [28] and Arias et al. [40]. However, it contradicted the findings of Rocas et al. [41] and Jaiswal et al. [7] who showed that both solutions were equally effective with no significant difference between them. This disagreement could be due to the different $\mathrm{NaOCl}(2.5 \%)$ concentration used in both studies which was lower than that used in the current study $(5.25 \%)$.

$\mathrm{NaOCl}$ exerts its antibacterial effects through many mechanisms; first the released hydroxyl ions destroy bacterial cell membranes and nucleic acid. The high $\mathrm{pH}$ then causes denaturation of bacterial proteins [42]. The released chloride ions play a significant role in $\mathrm{NaOCl}$ antimicrobial activity, being responsible for dissolving organic materials including bacterial biofilms [43]. However, $\mathrm{CHX}$ exerts its action by disrupting bacterial cell walls through adsorption onto phosphate containing proteins. It then forms irreversible precipitates with bacterial adenosine triphosphate and DNA after penetrating the bacterial cells resulting in bacterial cell death [41]

The ability of the irrigants to dissolve bacterial biofilms is directly related to its ability to kill microorganisms that lie within this biofilm. Therefore, the lack of any biofilm dissolving effect of $2 \% \mathrm{CHX}$ in comparison to $\mathrm{NaOCl}$ justifies the superior antibacterial effectiveness of $\mathrm{NaOCl}$ [43].

All tested irrigants showed significant antibacterial effects against aerobic bacteria. In the four groups a significant reduction in the aerobic bacterial colony count $(\mathrm{CFU} / \mathrm{ml})$ after preparation and irrigation was evident, with no significant difference among them.

The intensity of post-operative pain was highest in the first $24 \mathrm{~h}$ in all groups. It gradually decreased with time until reaching complete subsidence of pain (median $=0$ ) at $72 \mathrm{~h}$ postoperatively. This finding agrees with the previous studies since it has been generally proven that endodontically treated teeth exhibited higher levels of pain in the first $24 \mathrm{~h}$ after treatment and that post-operative symptoms gradually subside within 7 days after treatment [32], [33].

There was a significant difference in pain intensity among the four groups at 12 and $24 \mathrm{~h}$ postoperatively with the highest pain intensity values in the $\mathrm{NaOCl}$ group. The pairwise comparison revealed that patients in the $\mathrm{NaOCl}$ and $\mathrm{CHX}$ groups suffered from statistically higher pain levels compared to the patients in CNPs/CHX combination and CNPs groups.

The fact that CNPs and CNPs/CHX combination were accompanied by lower post-operative pain levels could be attributed to the biocompatibility of chitosan, being a natural polysaccharide with no 
reported cytotoxicity [7]. It was reported that CNPs were significantly less cytotoxic than chitosan itself owing to the cross linker in the CNPs [44]. These properties make CNPs more tissue friendly than both $\mathrm{NaOCl}$ and $\mathrm{CHX}$ if it gets extruded. Since the severity of postoperative pain might be related to extrusion of debris beyond the apex during root canal preparation [45] and Parirokh et al. [45] found significantly higher debris extrusion with $5.25 \% \mathrm{NaOCl}$ compared to $3 \% \mathrm{NaOCl}$ and $2 \% \mathrm{CHX}$, the prevalence of higher pain intensities in the $\mathrm{NaOCl}$ group in the study could be explained.

There was no significant difference between $\mathrm{CHX}$ and $\mathrm{NaOCl}$ regarding post-operative pain intensity, this result agreed with the findings of Almeida et al. [46] and Saba et al. [47] who found no significant difference between the two solutions and disagrees with the findings of Bashetty et al. [48] who showed that $5.25 \%$ $\mathrm{NaOCl}$ provoked significantly higher post-operative pain than $2 \% \mathrm{CHX}$.

\section{Conclusions}

Within the limitations of the current study, it was concluded that:

- $\quad 3 \%$ CNPs and its combination with $2 \% \mathrm{CHX}$ are significantly more effective than both $2 \%$ $\mathrm{CHX}$ and $5.25 \% \mathrm{NaOCl}$ against anaerobic bacteria isolated from mandibular premolars with necrotic pulps and are not significantly different from each other.

- $\quad$ The addition of $2 \% \mathrm{CHX}$ did not cause a significant improvement to the antibacterial effectiveness of $3 \%$ CNPs.

- Both 3\% CNPs and its combination with $2 \% \mathrm{CHX}$ were associated with lower postoperative pain scores than either $5.25 \% \mathrm{NaOCl}$ or $2 \% \mathrm{CHX}$.

- $\quad$ Post-operative pain values were highest in the first $24 \mathrm{~h}$ and gradually decreased over time until complete subsidence within a week.

\section{References}

1. SjogrenU, FigdorD, PerssonS, Sundqvist G. Influence of infection at the time of root filling on the outcome of endodontic treatment of teeth with apical periodontitis. Int Endod J. 1997;30(5):297-306. https://doi.org/10.1046/j.1365-2591.1997.00092.x PMid:9477818

2. Kapadia M, Srirekha A, Lekha S, Savitha B, Vijay R, Archana S. Comparative evaluation of chlorhexidine and its combination with chitosan as intracanal medicaments on Enterococcus faecalis in endodontic retreatment. Dentistry. 2018;8(7):8-11. https://doi.org/10.4172/2161-1122.1000502
3. Dutertre B, Bruinen Y. Role of codata-hdb in the centralization and distribution of information concerning the rat hybridomas. In: Rat Hybridomas and Rat Monoclonal Antibodies. Boca Raton, Florida: CRC Press; 2017. p. 475-8. https://doi. org/10.1201/9780203710579

4. Carson KR, Goodell GG, McClanahan SB. Comparison of the antimicrobial activity of six irrigants on primary endodontic pathogens. J Endod. 2005;31(6):471-3. https://doi. org/10.1097/01.don.0000148868.72833.62

PMid:15917691

5. Tennert C, Feldmann K, Haamann E, Al-Ahmad A, Follo $\mathrm{M}$, Wrbas $\mathrm{KT}$, et al. Effect of photodynamic therapy (PDT) on Enterococcus faecalis biofilm in experimental primary and secondary endodontic infections. BMC Oral Health. 2014;14(1):1-8. https://doi.org/10.1186/1472-6831-14-132

6. Shingare $P$, Chaugule V. Comparative evaluation of antimicrobial activity of miswak, propolis, sodium hypochlorite and saline as root canal irrigants by microbial culturing and quantification in chronically exposed primary teeth. Germs. 2011;1:12-21. https://doi.org/10.11599/germs.2012.1004 PMid:24432254

7. Jaiswal N, Sinha DJ, Singh UP, Singh K, Jandial UA, Goel S. Evaluation of antibacterial efficacy of chitosan, chlorhexidine, propolis and sodium hypochlorite on Enterococcus faecalis biofilm: An in vitro study. J Clin Exp Dent. 2017;9(9):e1066-74. https://doi.org/10.4317/jced.53777

PMid:29075407

8. Dunavant TR, Regan JD, Glickman GN, Solomon ES, Honeyman AL. Comparative evaluation of endodontic irrigants against Enterococcus faecalis biofilms. J Endod. 2006;32(6):527-31. https://doi.org/10.1016/j.joen.2005.09.001

PMid: 16728243

9. Zandi $H$, Rodrigues RC, Kristoffersen AK, Enersen $M$, Mdala I, Ørstavik D, et al. Antibacterial effectiveness of 2 root canal irrigants in root-filled teeth with infection: A randomized clinical trial. J Endod. 2016;42(9):1307-13. https://doi. org/10.1016/j.joen.2016.06.006

PMid:27452293

10. Ercan E, Ozekinci T, Atakul F, Gul K. Antibacterial activity of $2 \%$ chlorhexidine gluconate and $5.25 \%$ sodium hypochlorite in infected root canal: In vivo study. J Endod. 2004;30(2):84-7. https://doi.org/10.1097/00004770-200402000-00005 PMid:14977302

11. Shrestha A, Kishen A. Antibacterial nanoparticles in endodontics: A review. J Endod. 2016;42(10):1417-26. https:// doi.org/10.1016/j.joen.2016.05.021

PMid:27520408

12. Yadav P, Chaudhary S, Saxena RK, Talwar S, Yadav S. Evaluation of antimicrobial and antifungal efficacy of chitosan as endodontic irrigant against Enterococcus faecalis and Candida albicans biofilm formed on tooth substrate. $\mathrm{J}$ Clin Exp Dent. 2017;9(3):e361-7. https://doi.org/10.4317/jced.53210 PMid:28298975

13. Ballal NV, Kundabala M, Bhat KS, Acharya S, Ballal M, Kumar R, et al. Susceptibility of Candida albicans and Enterococcus faecalis to chitosan, chlorhexidine gluconate and their combination in vitro. Aust Endod J. 2009;35(1):29-33. https://doi.org/10.1111/j.1747-4477.2008.00126.x

PMid: 19452677

14. Skoskiewicz-Malinowska K, Kaczmarek U, Malicka B, Walczak K, Zietek M. Application of chitosan and propolis in endodontic treatment: A review. Mini Rev Med Chem. 2017;17(5):410-34. https://doi.org/10.2174/1389557516666160418122510 PMid:27087464

15. del Carpio-Perochena A, Kishen A, Felitti R, Bhagirath AY, 
Medapati MR, Lai C, et al. Antibacterial properties of chitosan nanoparticles and propolis associated with calcium hydroxide against single- and multispecies biofilms: An in vitro and in situ study. J Endod. 2017;43(8):1332-6. https://doi.org/10.1016/j. joen.2017.03.017

\section{PMid:28578886}

16. Dasilva L, Finer Y, Friedman S, Basrani B, Kishen A. Biofilm formation within the interface of bovine root dentin treated with conjugated chitosan and sealer containing chitosan nanoparticles. J Endod. 2013;39(2):249-53. https://doi. org/10.1016/j.joen.2012.11.008

PMid:23321239

17. Kishen A, Shi Z, Shrestha A, Neoh KG. An investigation on the antibacterial and antibiofilm efficacy of cationic nanoparticulates for root canal disinfection. J Endod. 2008;34(12):1515-20. https://doi.org/10.1016/j.joen.2008.08.035

PMid:19026885

18. Wu D, Fan W, Kishen A, Gutmann JL, Fan B. Evaluation of the antibacterial efficacy of silver nanoparticles against Enterococcus faecalis biofilm. J Endod. 2014;40(2):285-90. https://doi.org/10.1016/j.joen.2013.08.022 PMid:24461420

19. Hasanin MT, Elfeky SA, Mohamed MB, Amin RM. Production of well-dispersed aqueous cross-linked chitosan-based nanomaterials as alternative antimicrobial approach. J Inorg Organomet Polym Mater. 2018;28(4):1502-10. https://doi. org/10.1007/s10904-018-0855-2

20. Hulsmann M, Peters O, Dummer PM. Mechanical preparation of root canals: Shaping goals, techniques and means. Endod Top. 2005;10(10):30-76. https://doi. org/10.1111/j.1601-1546.2005.00152.x

21. Retamozo B, Shabahang S, Johnson N, Aprecio RM, Torabinejad M. Minimum contact time and concentration of sodium hypochlorite required to eliminate Enterococcus faecalis. J Endod. 2010;36(3):520-3. https://doi.org/10.1016/j. joen.2009.12.005 PMid:20171375

22. Roshdy NN, Kataia EM, Helmy NA. Assessment of antibacterial activity of $2.5 \% \mathrm{NaOCl}$, chitosan nano-particles against Enterococcus faecalis contaminating root canals with and without diode laser irradiation: An in vitro study. Acta Odontol Scand. 2018;77(1):39-43. https://doi.org/10.1080/00016357.20 18.1498125

PMid:30152712

23. Abdeltwab W, Abdelaliem $\mathrm{Y}$, Metry W, Eldeghedy $\mathrm{M}$. Antimicrobial effect of chitosan and nano-chitosan against some pathogens and spoilage microorganisms. J Adv Lab Res Biol. 2019;10(1):8-15.

24. Perinelli DR, Fagioli L, Campana R, Lam JK, Baffone W, Palmieri GF, et al. Chitosan-based nanosystems and their exploited antimicrobial activity. Eur J Pharm Sci. 2018;117:8-20. https://doi.org/10.1016/j.ejps.2018.01.046

PMid:29408419

25. Neves AS. Disinfecting oval-shaped root canals : Effectiveness of different supplementary approaches. J Endod. 2011;37(4):496501. https://doi.org/10.1016/j.joen.2010.12.008

PMid:21419297

26. Vijaykumar S, GunaShekhar M, Himagiri S. In vitro effectiveness of different endodontic irrigants on the reduction of Enterococcus faecalis in root canals. J Clin Exp Dent. 2010;2(4):1865-71. https://doi.org/10.4317/jced.2.e169

27. Goud S, Aravelli S, Dronamraju S, Cherukuri G. Comparative evaluation of the antibacterial efficacy of aloe vera, $3 \%$ sodium hypochlorite, and $2 \%$ chlorhexidine gluconate against Enterococcus faecalis: An in vitro study. Cureus. 2018;10(10):e3480. https://doi.org/10.7759/cureus.3480

\section{PMid:30648031}

28. Agrawal V, Rama Rao MS, Dhingra K, Gopal VR, Mohapatra A Mohapatra A. An in vitro comparison of antimicrobial efficacy of three root canal irrigants-BioPure MTAD, $2 \%$ chlorhexidine gluconate and $5.25 \%$ sodium hypochlorite as a final rinse against E. faecalis. J Contemp Dent Pract. 2013;14(5):842-7. https://doi.org/10.5005/jp-journals-10024-1413 PMid:24685785

29. Siqueira J, Rôças I. Microbiology and Treatment of Endodontic Infections. In: Cohen's Pathways of the Pulp. 11th ed. Amsterdam, Netherlands: Elsevier; 2011. p. 559-600. http://doi. org/10.1016/B978-0-323-06489-7.00015-1

30. Williamson A, Hoggart B. Pain: A review of three commonly used pain rating scales. J Clin Nurs. 2005;14(7):798-804. https://doi. org/10.1111/j.1365-2702.2005.01121.x

PMid: 16000093

31. Ahmed S, Ahmed A, Sikader M. Comparison of post operative pain frequency after single visit and multiple visits root canal treatment with rotary instruments on non-vital teeth. Pak Oral Dent J. 2017;37(1):158-60.

32. Gambarini G, Sudani DA, Di Carlo S, Pompa G, Pacifici A, Pacifici $L$, et al. Incidence and intensivity of postoperative pain and periapical inflammation after endodontic treatment with two different instrumentation techniques. Eur J Inflamm. 2012;10(1):99-103. https://doi. org/10.1177/1721727x1201000111

33. Chhabra A, Katna M, Garg N, Chhabra V. Influence of three different instrumentation techniques on the incidence of postoperative pain after endodontic treatment. Pesqui Bras Odontopediatr Clin Integr. 2018;18(1):152-5. https://doi. org/10.4034/pboci.2018.181.77

PMid:23741536

34. Wang C, Xu P, Ren L, Dong G, Ye L. Comparison of postobturation pain experience following one-visit and two-visit root canal treatment on teeth with vital pulps: A randomized controlled trial. Int Endod J. 2010;43(8):692-7. https://doi. org/10.1111/j.1365-2591.2010.01748.x PMid:20491987

35. Viyera PJ, Guardado A. Incidence and severity of post operative pain following root canal treatment of teeth with non vital pulps using hand and rotary instrumentation techniques. Endod Pract. 2009;1:27-30.

36. del Carpio-Perochena A, Bramante CM, Duarte MAH, de Moura MR, Aouada FA, Kishen A. Chelating and antibacterial properties of chitosan nanoparticles on dentin. Restor Dent Endod. 2015;40(3):195-201. https://doi.org/10.5395/ rde.2015.40.3.195 PMid:26295022

37. Moukarab DA. Evaluation of antimicrobial activity of manually agitate (nano chitosan and nano propolis) against enterococcus faecalis in comparison with sodium hypochlorite: An in-vitro study. Egypt Dent J. 2020;66(1):587-96. https://doi. org/10.21608/edj.2020.79132

38. Barreras US, Méndez FT, Martínez RE, Valencia CS, Rodríguez PR, Rodríguez JP. Chitosan nanoparticles enhance the antibacterial activity of chlorhexidine in collagen membranes used for periapical guided tissue regeneration. Mater Sci Eng C. 2016;58:1182-7. https://doi.org/10.1016/j.msec.2015.09.085 PMid:26478419

39. Hong L, Luo SH, Yu CH, Xie Y, Xia MY, Chen GY, et al. Functional nanomaterials and their potential applications in antibacterial therapy. Pharm Nanotechnol. 2019;7(2):129-46. PMid:30894114

40. Arias-Moliz MT, Ordinola-Zapata R, Baca P, Ruiz-Linares M, García García E, Hungaro Duarte MA, et al. Antimicrobial activity of chlorhexidine, peracetic acid and sodium hypochlorite/ 
etidronate irrigant solutions against Enterococcus faecalis biofilms. Int Endod J. 2015;48(12):1188-93. https://doi. org/10.1111/iej.12424

PMid:25515403

41. Rôças IN, Provenzano JC, Neves MA, Siqueira JF. Disinfecting effects of rotary instrumentation with either $2.5 \%$ sodium hypochlorite or $2 \%$ chlorhexidine as the main irrigant: A randomized clinical study. J Endod. 2016;42(6):943-7. https:// doi.org/10.1016/j.joen.2016.03.019

PMid:27142579

42. Darcey J, Jawad S, Taylor C, Roudsari RV, Hunter M. Modern endodontic principles part 4: Irrigation. Dent Update. 2016;43(1):20-33. https://doi.org/10.12968/denu.2016.43.1.20 PMid:27024899

43. Del Carpio-Perochena AE, Bramante CM, Duarte MA, Cavenago BC, Villas-Boas MH, Graeff MS, et al. Biofilm dissolution and cleaning ability of different irrigant solutions on intraorally infected dentin. J Endod. 2011;37(8):1134-8. https:// doi.org/10.1016/j.joen.2011.04.013

PMid:21763908

44. Pistone S, Goycoolea FM, Young A, Smistad G, Hiorth M. Formulation of polysaccharide-based nanoparticles for local administration into the oral cavity. Eur J Pharm Sci.
2017;96:381-9. https://doi.org/10.1016/j.ejps.2016.10.012

PMid:27721043

45. Parirokh M, Jalali S, Haghdoost AA, Abbott PV. Comparison of the effect of various irrigants on apically extruded debris after root canal preparation. J Endod. 2012;38(2):196-9. https://doi. org/10.1016/j.joen.2011.10.027

PMid:22244635

46. Almeida G, De Martin AS, da Bueno CE, Nowakowski A, Cunha RS. Influence of irrigating solution on postoperative pain following single-visit endodontic treatment: Randomized clinical trial. J Can Dent Assoc. 2012;78:C84

PMid:22985896

47. Saba K, Maxood A, Abdullah S, Riaz A, Uddin S. Comparison of frequency of pain in root canal treatment using sodium hypochlorite and chlorhexidine as root canal irrigants. J Pak Med Assoc. 2018;68(9):1334-8. https://doi.org/10.1016/j.joen.2011.10.027 PMid:30317260

48. Bashetty K, Hegde J. Comparison of $2 \%$ chlorhexidine and $5.25 \%$ sodium hypochlorite irrigating solutions on postoperative pain: a randomized clinical trial. Indian J Dent Res. 2010;21(4):523-7. https://doi.org/10.4103/0970-9290.74225

PMid:21187618 